\title{
A potash solution to combat molluscum contagiosum where potash is to be considered a buffering agent in an acidic solution, instead to be designed as the very remedy, in men and women.
}

\author{
Texia Research ${ }^{1}$, Lorenzo Martini² \\ ${ }^{1}$ Texia Research-Eu-TURIN, ${ }^{2}$ Department of Pharmaceutical Biotechnologies University of Siena
}

\begin{abstract}
Molluscum contagiosum is a relatively common viral infection of the skin that results in painless bump. If the bumps are scratched or injured, the infection can spread to surrounding skin. Though most common in children, molluscum contagiosum can affect adults as well-particularly those with weakened immune systems. In adults with an otherwise normal immune system, molluscum contagiosum involving the genitals is considered a sexually transmitted infection. It is not lethal otherwise it is contagious and unesthetic. Purpose of our study is to propose an official and well recognised remedy, based on a 10\% potash solution, that can be eradicate the viral infections (owing to IgM and IgG antibodies tests) I 12 days, highlighting the fact that the simplest application os potassa solution, as many hospitals in the world, employ commonly as unique remedy, gives results that too often are not satisfactory at all. The trick resides in an inverse buffered solution, where $\mathrm{KOH}$ results the buffering agent and not the medicine itself.We have recruited 6 cases, almost particular.
\end{abstract}

Keywords: Molluscum contagiosum, potash, caprylica acid,buffer, Balsamum de San Salvador.

\section{Background}

Molluscum contagiosum is a relatively common viral infection of the skin that results in round, firm, painless bumps ranging in size from a pinhead to a pencil eraser. If the bumps are scratched or injured, the infection can spread to surrounding skin. Though most common in children, molluscum contagiosum can affect adults as well - particularly those with weakened immune systems. In adults with an otherwise normal immune system, molluscum contagiosum involving the genitals is considered a sexually transmitted infection. Molluscum contagiosum spreads through direct person-to-person contact and through contact with contaminated objects. The bumps associated with molluscum contagiosum usually disappear within a year without treatment but doctor-assisted removal can be considered as well an option.

More widespread molluscum contagiosum infections may occur in people with weakened immune systems and in children who have atopic dermatitis.(1-14) So an atopic dermatitis that is not properly treated, can lead to the insurgence of the virus of the molluscum contagiosum.Signs and symptoms of molluscum contagiosum include bumps on the skin that are raised, round and flesh coloured, small - typically under about $1 / 4$ inch in diameter, they characteristically have a small indentation (umbilication) or dot at the top near the center. They become red and inflamed and itchy and therefore may be easily removed by simple scratching or rubbing, which can spread the virus to adjacent skin.

They usually appear on the face, neck, armpits, arms and tops of the hands in children, howbeit they may be seen on the genitals, lower abdomen and inner upper thighs in adults if the infection was sexually transmitted. The chief causes that permit the virus of molluscum contagiosum spreads easily through:

a) Direct skin-to-skin contact

b) Contact with contaminated objects, such as toys, towels and faucet handles

c) Sexual contact with an affected partner

d) During any type of sexual activity, contact sports, or other activity that involves touching the bumps of an infected person.

e) Through contact with a towel, washcloth or something else that has the virus on it.

f) To other parts of an infected person's body by rcratching the bumps.

The bumps and the skin around them may become red and inflamed. This is thought to be an immune response to the infection. If scratched, these bumps can become infected. If lesions appear on the eyelids, conjunctivitis can develop. Amongst the medical remedies one may number: Irritating lotions or apozemas: that contain Salicylic acid and/or Zinc chloride and/or Strontium Sulfide saturated solutions, that help dissolve the lesion over time. Others may cause a blister to form under the bump, lifting it off your skin.

Herbs and dangerous secretes from Insects: Podophyllum peltatum pulvis (for instance: the Dobell's concrete, that consists in a $0.5 \%$ podophyllin powder mix in ginger extract and ethanol; the Van der Corput's mixture, that consists in $0.02 \%$ podophyllinum powder solution in sapo medicinalis saturated solution); 
Cantharis powder (for instance: Emplastrum from the Pharmacopoeia Helvetica that forecasts cantharis powder, bees wax, turpentine and Balsamum de San Salvador; or the Emplastrum d'Albespeyres, (from Ergaenzarzneibuch), that prescribes cantharis powder, tallow, pix graeca. Benzoin styrax).

Topical emulsions and gélées: that contain large dosages of retinoids, adapalene and tazarotene have been frequently used to treat molluscum contagiosum.(15-23) These medications cannot be absolutely used during pregnancy or lactation. Some Turkish AA. (24) refer that Potassium Hydroxide solution is able to smooth, polish and sanitize bumps, but only a pure $10 \% \mathrm{KOH}$ solution can fully eradicate the molluscum contagiosum infections.

They employ a simplest $10 \% \mathrm{KOH}$ solution to brush upon bumps, obtaining very excellent results.

I have prior tried to let some volunteers suffering from mollusca (they correspond to the object of my study and are represented by 6 cases), but as just water evaporates, $\mathrm{KOH}$ scales and crusts, and sensation of reddening and burn begins almost intolerable. Moreover a $10 \% \mathrm{KOH}$ solution has a $\mathrm{pH} 14$, that is not admitted in cosmetic items. $\mathrm{KOH}$ is allowed when the formula has to be adjusted at $\mathrm{pH}$ 11. Notwithstanding, following the Henderson-Hasselbach's rule, the formulator of the mixture I decided to use on the volunteers, made up his mind to choose an acidic solution and to adjust $\mathrm{pH}$ from 2.2 till 11, as prescribed. Actually, the only acids that are useful to combat mollusca should be the dichloroacetic and trichloroacetic ones, albeit they are not allowed in INCI.The cosmetic engineer has surely supposed that the $\mathrm{pH}$ of a very strong acidic solution could easily buffered owing to the addition of an alkaline buffer (idest $\mathrm{KOH}$ ). Following this reasoning I have discovered that the formulation contains two organic acids (the former is the citric acid in large proportions) and the latter is the caprylic acid, and so the buffering effect of $\mathrm{KOH}$ may be even postulated, and effectively it is amply justified.

The composition I have tried (it is a medical device) contains collodion, an elastic jelly solution containing nitrocellulose, ethanol, water and alcohol,(colophonia and balsamum pereirae) apt to let the potash to adhere to the bumps, exorcising the water evaporation and encourage the full and progressive penetration of the potash itself through the first epidermal stratum in order to treat the lesions evoked by the virus. The formula (quasi-unknown for me because of industrial reasons of confidentiality) contains an acidic solution ( at $\mathrm{pH} 1,5)$ of citric acid and caprylic acid which, owing to the addiction of a solution of $\mathrm{KOH}$, reaches a final $\mathrm{pH} 11$, rendering the final mix allowable in cosmetic items, and thus can be identified as a medical device.

\section{Materials and Methods}

I have recruited 4 plumbers (A,B,C,D) who presented molluscum contagiosum infections on both the hands (one of them, Case C, shows bumps even on his inguinal area, even he strenuously affirms that it is due to the fact that when he is at work he cannot wash always his hands before to go to toilet and too often even after used the closet) and a young man (21y.old) (E) that likes transvestism and during week ends frequents some kinds of special locations where straight men like to have amusement with transvestites and he suffers from molluscum virale infections inside his anal areas, a woman (an agée madame) (F) who suffers from molluscum after a promiscuous sexual intercourse with a gigolo who transmitted to her intimate mucosae the bumps.All 6 volunteers accepted willingly to try the medical device.

The evaluation tests I have chosen to reveal the final defeat of the viral infection after the treatment with the medical device is the Vaughn Nisalak's test, consisting in the determination of the pools of IgM and IgG in volunteers' sera, at the beginning, during and at the end of the experience. Objectively at the very beginning all the 6 individuals resulted positive for IgM antibodies (because of the presence of the viral infection of Molluscum) and positive for IgG antibodies, as well. The Immunoglobulin test must be repeated at the $7^{\text {th }}$ day and finally at the $12^{\text {th }}$ day. It is well known that when the individual's results are negative to IgM, the virus has been defeated, and similarly the sign that IgG are no more present in serum, is index of the eradication of the virus itself.

\section{Results}

Here follows Table I where the Immunoglobulins test values are scored at $1^{\text {st }}, 7^{\text {th }}$ and $12^{\text {th }}$ day.Legenda: $\mathrm{N}=$ negative

$\mathrm{P}=$ positive

\begin{tabular}{|l|l|l|l|l|l|l|}
\hline Case & IgM at $1^{\text {st }}$ day & IgG at $1^{\text {st }}$ day & IgM at $7^{\text {th }}$ day & IgG at $7^{\text {th }}$ day & IgM at12 $2^{\text {th }}$ day & IgG at12 $2^{\text {th }}$ day \\
\hline A & P & P & P & P & N & N \\
\hline B & P & P & N & P & N & N \\
\hline C & P & P & N & P & N & N \\
\hline D & P & P & P & P & N & P \\
\hline E & P & P & P & P & N & N \\
\hline F & P & P & & \\
\hline
\end{tabular}




\section{Discussions and Conclusion}

After 12 days of application of the medical device, the 6 volunteers showed negative IgG result coupled with a negative IgM result indicating the total absence of virus (even if these values could indicate a nonimmunity state). The fact that Case E, the transvestite, is positive for IgG, means surely that he has had a previous asymtomatic contact, but it is comforting that he is negative to IgM, idest the noxia (the virus of the molluscum contagiosum) disappeared.

\section{Aknowledgement}

I have sincerely to thank Prof Lorenzo Martini who helped me to find right volunteers, so difficult to be retrieved and disposed to employ a medical device, my firm Texia-Turin, numbers amongst all its dermal cosmetological items.

\section{References}

[1]. Silverberg NB, Sidbury R, Mancini AJ. Childhood molluscum contagiosum: Experience with cantharidin therapy in 300 patients. J Am Acad Dermatol. 2000;43:503-507.

[2]. British Association for Sexual Health and HIV. UK national guideline for the management of genital molluscum in adults 2014. July 2014.

[3]. van der Wouden JC, van der Sande R, van Suijlekom-Smit LW, et al. Interventions for cutaneous molluscum contagiosum. Cochrane Database Syst Rev. 2009;(4):CD004767.

[4]. Theos AU, Cummins R, Silverberg NB, et al. Effectiveness of imiquimod cream $5 \%$ for treating childhood molluscum contagiosum in a double-blind, randomized pilot trial. Cutis. 2004;74:134-138, 141-142.

[5]. Hanna D, Hatami A, Powell J, et al. A prospective randomized trial comparing the efficacy and adverse effects of four recognized treatments of molluscum contagiosum in children. Pediatr Dermatol. 2006;23:574-579.

[6]. Al-Mutairi N, Al-Doukhi A, Al-Farag S, et al. Comparative study on the efficacy, safety, and acceptability of imiquimod 5\% cream versus cryotherapy for molluscum contagiosum in children. Pediatr Dermatol. 2010;27:388-394.

[7]. Sturt RJ, Muller HK, Francis GD. Molluscum contagiosum in villages of the West Sepik District of New Guinea. Med J Aust. 1971;2:751-55

[8]. Becker TM, Blount JH, Douglas J, et al. Trends in molluscum contagiosum in the United States, 1966-1983. Sex Transm Dis. 1986;13:88-89

[9]. Pannell RS, Fleming DM, Cross KW. The incidence of molluscum contagiosum, scabies and lichen planus. Epidemiol Infect. 2005;133:985-991.

[10]. Silverberg NB, Sidbury R, Mancini AJ. Childhood molluscum contagiosum: Experience with cantharidin therapy in 300 patients. J Am Acad Dermatol. 2000;43:503-507.

[11]. Oren B, Wende SO. An outbreak of molluscum contagiosum in a kibbutz. Infection. 1991;19:159-161.

[12]. Braue A, Ross G, Varigos G, et al. Epidemiology and impact of childhood molluscum contagiosum: a case series and critical review of the literature. Pediatr Dermatol. 2005;22:287-294.

[13]. Dohil M, Prendiville JS. Treatment of molluscum contagiosum with oral cimetidine: clinical experience in 13 patients. Pediatr Dermatol. 1996;13:310-312.

[14]. Dohil MA, Lin P, Lee J, et al. The epidemiology of molluscum contagiosum in children. J Am Acad Dermatol. 2006;54:47-54.

[15]. British Association for Sexual Health and HIV. UK national guideline for the management of genital molluscum in adults 2014. July 2014. http://www.bashh.org/ (last accessed 12 May 2015).

[16]. Handjani F, Behazin E, Sadati MS. Comparison of $10 \%$ potassium hydroxide solution versus cryotherapy in the treatment of molluscum contagiosum: an open randomized clinical trial. J Dermatolog Treat. 2014;25:249-250.

[17]. Köse O, Özmen İ, Arca E. An open, comparative study of 10\% potassium hydroxide solution versus salicylic and lactic acid combination in the treatment of molluscum contagiosum in children. J Dermatolog Treat. 2013;24:300-304.

[18]. van der Wouden JC, van der Sande R, van Suijlekom-Smit LW, et al. Interventions for cutaneous molluscum contagiosum. Cochrane Database Syst Rev. 2009;(4):CD004767.

[19]. Syed TA, Lundin S, Ahmad M. Topical $0.3 \%$ and $0.5 \%$ podophyllotoxin cream for self-treatment of molluscum contagiosum in males.Aplacebo-controlled,double-blindstudy.Dermatology.1994;189:65-68.

[20]. Chathra N, Sukumar D, Bhat RM, et al. A comparative study of $10 \% \mathrm{KOH}$ solution and $5 \%$ imiquimod cream for the treatment of Molluscum contagiosum in the pediatric age group. Indian Dermatol Online J. 2015;6:75-80.

[21]. Ronnerfalt L, Fransson J, Wahlgren CF. EMLA cream provides rapid pain relief for the curettage of molluscum contagiosum in children with atopic dermatitis without causing serious application-site reactions. Pediatr Dermatol. 1998;15:309-312.

[22]. Hanna D, Hatami A, Powell J, et al. A prospective randomized trial comparing the efficacy and adverse effects of four recognized treatments of molluscum contagiosum in children. Pediatr Dermatol. 2006;23:574-579.

[23]. Ormerod AD, White MI, Shah SA, et al. Molluscum contagiosum effectively treated with a topical acidified nitrite, nitric oxide liberating cream. Br J Dermatol. 1999;141:1051-1053.

[24]. Can B, Topaloğlu F, Kavala M, Turkoglu Z, Zindancı I, Sudogan S: Treatment of pediatric molluscum contagiosum with 10\% potassium hydroxide solution;J Dermatolog Treat.2014 Jun;25(3):246-8. 